\title{
One hundred years of the Biologische Anstalt Helgoland on the island of Helgoland, a cliff in the North Sea steeped in the tides and currents of history
}

\author{
W. Gunkel \\ Biologische Anstalt Helgoland (Zentrale); Notkestr. 31, D-22607 Hamburg, Germany
}

Ladies and Gentlemen,

Jubilees tend to make us so proud that we deal with the past in a rather complacent manner. We state what has been achieved and then praise ourselves for the achievements.

When the German poet and philosopher G. E. Lessing was asked why we are concerned with history, he answered that we study history to illuminate our minds, and not to overload our memories.

We, today, should ask ourselves the same question: why, or for what purpose, do we occupy ourselves with the history of a research institute, for example with that of the Biologische Anstalt Helgoland? The answer is: we want to achieve a clear idea of the status quo of the research carried out, and define what we have learned from the past, so that it may guide us in the future. At this point, we should quite seriously ask ourselves whether we are carrying out research in the proper way, and have the demands, claims, plans, intentions and dreams of the past been fulfilled?

Science is the desire of the inquisitive to illuminate and explain the unknown. It also offers us methods to solve the problems of an environment - used, misused, abused, polluted and exploited by man - that pose a serious threat to humankind's future survival.

The second half of the last century was indeed a period of scientific and technical change, of reorientation, that gave birth to new ideas. A marked improvement in the standard of living took place, with a general increase in wealth, and this brought us material goods that we now take for granted and which we cannot do without, even if we in some instances realize that we are hooked, or that these, like a ball and chain, fetter and restrain us from freedom of action. Having grasped this, we have, in the course of the last decade, developed a more critical attitude.

Despite this, which European or American can envisage life without electricity, without a car, without the railway, without a telephone, or without motorized ships? 100 years seem a long time, but many of those present have already lived for half a century, 
many have carried out research for half a century, and more than likely we all have some idea of the whole of the last century from the stories told us by our parents and grandparents.

In these past 100 years the foundations were laid for the science of hygiene and bacteriology. Anaesthetics were used for the first time; tuberculosis was defeated; Mendel's laws were rediscovered, and gene transfer became possible. The past hundred years made it possible for us all, no matter what our occupation, to have a paid holiday, which led finally to mass tourism with all its side-effects.

The population of the human race has increased by several billion. Certainly, large groups of the population have achieved greater wealth, and, due to inequality of distribution, other groups have become poorer, and famine has set in. The past 100 years have brought us two world wars and more than 100 serious localised military conflicts; they have also brought us atomic power and the atom bomb, and a severe economic depression. For the first time, the number of students in Germany exceeds one million.

In 1859, Charles Darwin published "The origin of species by means of natural selection." This work, which marked the beginning of - a new era, gave a new and unexpected impetus to contemporary biology, which was in a state of stagnation. Darwin's ideas attracted many scientists, for example Anton Dohrn, encouraging them to carry out both intensive and extensive investigations of the fauna and flora of land and sea - especially of the latter, as this contained many unknown species that had not yet been described. While a part of these papers was written with the intention of searching for new proof for, and additions to, Darwin's theory of evolution, all of them were on the whole characterized by an admiration for the variety of life in the sea. A good example is the book by Haeckel, "Kunstformen der Natur". ("Nature's works of art").

At first, very few had the possibility of working from on board a ship. But in the second half of the last century many marine stations and institutions sprang up in quick succesion. To name just a few, in France: Arcachon and Banyuls in 1863, Roscoff in 1872, Villefranche sur Mer in 1880. In Great Britain: Millport was founded in 1885, Plymouth in 1888. As early as 1871 a station was founded in Sebastopol; even Australia had a station by 1878 . In the USA, Pacific Grove was established in 1892, and in the same year, Bergen, in Norway.

Up until 1892, Germany had no marine research station on its home territory. The German zoologist, Anton Dohrn, had, however, established a zoological station in Naples in 1873 that was to become exemplary for many future institutes. The station, which Dohrn had financed from his own private funds, supported itself to a major degree by exacting entrance fees for the aquarium and by charging visiting scientists for the use of its facilities, ('Arbeitsplatzgebühren'). Later on it was supported by the German government.

German biologists had worked along the coasts of their country before, but they did not have a home base at their disposal; Helgoland, however, was a favoured destination of their excursions. There, in 1836, Ehrenbaum discovered that Noctiluca was the cause of luminescence of the sea, and he described this for the first time. A photograph taken in 1865 shows Anton Dohrn and Haeckel, together with three other zoologists on Helgoland, posing with small plankton nets in their hands.

The need for a German station became more and more obvious, and was expressed by single researchers and societies, such as the German Zoological Society, the German 
Botanical Society and the German Society for Scientists and Physicians. After Helgoland was handed over to Germany in 1890, the "Königliche Preußische Biologische Anstalt auf Helgoland" was founded, even if, at this stage, the framework was very modest. The hard work, effort and circumstances that led to the foundation of this station are described in detail in the commemorative volume published by the German Zoological Society, and also in the manuscript by P. Werner covering the history of the Biologische Anstalt Helgoland from its foundation up to 1945 . The latter will be published in 1993, in the series "Helgoländer Meeresuntersuchungen".

There were two main reasons for selecting Helgoland as the location for the first German marine station:

(1) Helgoland is situated approximately $60 \mathrm{~km}$ from the coast of the mainland, and is thus far away from the direct influence of the important rivers Elbe, Weser and Rhine. The salinity of the waters around Helgoland is similar to that of the open North Sea, even though a slight admixture of fresh water can be traced. What seemed at first to be an advantage regarding only salinity, proved later to be a significant advantage. The position of Helgoland away from the mainland means that the pollution caused by the rivers reaches it only in a highly diluted form;

(2) Helgoland is a rocky island, "a cliff in the sea". Its formation began 65 million years ago. The lower salt layers pushed up the upper layers of limestone and variegated sandstone. This process did not end until about two million years ago. A mountain-like area formed, measuring about $30 \mathrm{~km}^{2} .120000$ years ago, during the glacial period, glaciers smoothed the surface of this mountainous region. Erosion by the sea and weather has changed the face of Helgoland, and is still in process today. A terrace, several square kilometers in area, has formed in the tidal zone: the rocky flats, the 'Felswatt'.

A unique ecosystem has developed in this area. It is the only location in Germany where macroalgae have been able to develop in ribbon-like groups, dependent, of course, on the water depth since they need firm substrate to which they can attach. Similarly, the fauna of this area is also unique; at low tide, these rocky flats are high and dry, and it becomes possible to walk on the now dry sea-bed. No marine biologist can resist the fascination of these rocky flats, and every year up to 1000 students partake of this experience.

\section{The first director and the early period}

Friedrich Heincke was called to be the first director of the "Königliche Biologische Anstalt auf Helgoland". He had already gained international renown through his investigations on herring and on questions concerning the protection of stocks. He introduced quantitative methods, especially with regard to fish recruitment. He went on sea expeditions with the plankton expert Hensen, from Kiel. The zoologist, Hartlaub, became a valuable assistant, whose duty it was to look after the "ambulant" scholars, i.e. the visiting scientists. Heincke's second assistant was Ehrenbaum, who was entrusted with investigations that were of interest to the fisheries. Besides these, the algologist Kuckuck was active - even though his budgeted salary could not be paid until a later date.

Right from the foundation of the $\mathrm{BAH}$, working-space was made available for visiting scientists: Courses for students were not introduced until the 1920 s.

It is interesting to take a look at the list of publications by BAH scientists. They are characterizen by a basic solidity and intellectual integrity, and they have played a vital 
role in the foundation of the complex of marine biology. They have been published in reputable journals. It is also a pleasure to look through more modern publications, e.g. that of Sinclair \& Solemdad, issued by ICES, and bearing the title, "The development of population thinking in fisheries biology between 1878 and 1930", and to find there a tribute to Heincke's work and to the fact that he, at that very early date, carried out quantitative investigations that today would be considered modern.

\section{Long-term investigations}

A particular characteristic of the BAH is that certain aspects of research have been treated with a high measure of continuity. Continuity of this kind that builds up a treasure trove of experience is not possible unless an essential part of the scientific positions is firmly anchored in the budget of the institute. Continuity in research cannot in any way be achieved by creating positions in time-limited projects.

With reference to this problem, I should like to mention three groups of topics:

(1) Fish larvae and the recruitment of fish, especially of herring, were objects of intensive study by Heincke, who carried out many of his investigations with the help of Ehrenbaum. Mielck continued this work, but put emphasis on different aspects. Bückmann, Rosenthal and von Westernhagen carried on in the same field, whereby the latter two scientists focussed on ecological problems, either concerning nutrition or, as in von Westernhagen's and Cameron's work, on hatching-success and the damage caused by anthropogenic contaminants. These investigations also examined the occurrence of deformations. This work was supplemented by investigations by Köhler-Günther on the pathological changes in the livers of fish.

(2) Similarly, a 100-year-survey has been made of the algae at the BAH. Kuckuck started the initial studies on the Helgoländer 'Felssockel', the projecting rocky strata on the Helgoland coast. He examined the stocks and studied the life history, especially of the brown algae. Schreiber improved the methods of cultivation by introducing the use of a solution that is still named "Schreiberlösung".

Kornmann ${ }^{\dagger}$ has devoted a life-long study to the occurrence, the reproduction, and the life-history of the algae of Helgoland, working daily, at over 80 years of age, in the institute.

About 30 years ago, Lüning took up his studies on the photobiology and ecophysiology of macroalgae.

(3) The third subject-group is plankton research. Preliminary investigations focussed on fish larvae as part of the zooplankton. Mielck, Künne and Wulf concentrated on the occurrence of phyto- and zooplankton, on species-composition and their dependence on nutrients, whereby the biological aspects of production were considered. Aurich continued this work from the end of the 1930s, and Gillbricht carried on in the years following the Second World War. Even though salinity and temperature have been measured by daily sampling since the end of the last century, we are essentially obliged to Gillbricht for the fact that, from 1962 onwards, a series of long-term measurements has been carried out at Helgoland, comprising phytoplankton species composition and

\footnotetext{
* Professor Kornmann died on 20th August 1993
} 
amount, as well as a very large number of nutrients and chemical parameters. These measurements were extended to cover quantitative determinations of saprophytic bacteria, oil-degrading bacteria, yeast fungi, and of the surface tension of seawater. These investigations at the Kabeltonne near Helgoland, which is anchored between the main island and the Düne (Helgoland-Roads), constitute the longest available series of measurements concerning the sea. This series provides us with valuable information on the changes taking place in the sea, but it also draws our attention to the high natural variations, and how difficult it is to make clear statements on the effects of anthropogenic contaminants. This series of measurements was begun in 1962 by the $\mathrm{BAH}$, long before programmes monitoring the pollution of the sea were established.

Finally I would like to mention the work of Uhlig, who for nigh on three decades examined the occurrence, the distribution, and the ecology of Noctiluca miliaris. He carried on von Ehrenberg's investigations, which the latter made in 1835 on Helgoland and which led, as already mentioned, to the identification of this dinoflagellate as the cause of luminescence of the sea.

\section{The past 100 years}

In the past 100 years, highly significant political and economic events have had a major influence on the $\mathrm{BAH}$ and its scientific work.

The two world wars brought research almost completely to a standstill. In addition, the years after the First World War and the period following 1933 brought us scientific isolation.

The world-wide economic crisis at the end of the 'twenties prevented the completion of a new building for almost a decade. At the end of the Second World War, the BAH and the whole village of Helgoland were destroyed by bombing, and the island had to be evacuated for seven years.

Under extremely difficult circumstances, the BAH was kept alive by Hagmeier, Director of the BAH at that time.

Two rooms, placed at the disposal of the BAH by the Nursery Gardeners Cordes, in Wedel near Hamburg, served as a meeting place subsequent to the evacuation from Helgoland.

For many years, the colleagues of the BAH worked in the former fiscal oyster station in List, on Sylt and in an old naval shed. Conditions were bleak, to say the least. Dr. Ziegelmeyer started his work in a position intended for a part-time cleaning-woman.

Under the directorship of Hagmeier, the planning procedure for a new building on Helgoland was carried out, but it was not until 1959 that his successor Bückmann had the honour of opening the marine station and the aquarium on Helgoland.

Following this period, Kinne took over the directorship of the BAH for two decades. A major expansion took place. The number of staff members increased and new buildings were erected, among these the new Wadden Sea Station in List, on Sylt, the Experimental-Ecological Laboratory on Helgoland, and the Central Institute in Bahrenfeld, Hamburg. Active support from the Deutsche Forschungsgemeinschaft enabled us to provide modernized laboratory facilities for visiting scientists.

The courses for students began again in two lecture rooms on Helgoland, the number of research vessels was also increased. 
The successful international symposia, initiated by Kinne, proved to be especially rewarding scientifically. Between 1962 to 1983,10 symposia were organized and were held mainly on Helgoland. These made it possible for marine biologists from all over the world to get together and exchange their ideas and their results. Many returned to Helgoland as visiting scientists and spent many a month - and many a year - carrying out research with us.

The basic facts of the BAH as it now stands (1992) are as follows:

Number of staff: 176; number of scientists: 54; of these, 18 are externally supported.

Total expenditure (total budget) amounted to 18.4 million Deutsche Mark in 1991. The number of visiting scientists who conducted their own research projects rapidly increased to 231 in 1991.

The BAH comprises the Central Institute in Hamburg, the Marine Station on Helgoland, and the Wadden Sea Station Sylt, in List on the island of Sylt.

Generally speaking, the tasks assigned to the BAH have only partially changed over the past 100 years.

The BAH carries out basic marine biological research, acting as a competent partner for universities and other research institutes.

It conducts research aimed at recognizing, preventing and combatting pollution of the sea, and at using the sea as a source of food.

It directs monitoring programmes in the North Sea.

It serves the needs of other institutions and individuals by providing research facilities and technical assistance for visiting scientists. It also provides educational and research institutes on the mainland with marine organisms for educational purposes. It is entrusted with the legal administration of the Taxonomy Group, which is responsible for investigating biological material collected by German research vessels.

The research programme and plans for development of the BAH for the years 1992 and 1993 will focus on the following:

(1) The dynamics of biological processes in the Wadden Sea;

(2) Ecological interactions in the Wadden Sea;

(3) Structural and functional adaption of marine organisms;

(4) Research into marine pollution.

Thereby, it becomes quite clear that our work not only focusses on investigations of marine organisms and how they live in the sea, but also on the network of the total interactions of the organisms with their habitat.

After all, ecosystem research of this kind intends not only to make qualitative descriptions, but also wishes to be in a position to make quantifying prognoses on biogeochemical reactions in this the largest biosphere on earth.

The Biologische Anstalt Helgoland is a research institute under the auspices of the Federal Ministry of Research and Technology. The Ministry has always supported the BAH very generously and has shown an understanding of our affairs. I should like to express our sincere gratitude to the Ministry for this help and understanding. Our thanks are also due to its members, who have never denied us their support even through, sometimes, the dialogue between the adminstration and scientists is not very easy.

Today, on its centennial, the BAH should have every reason to be optimistic about its future! 
It has dedicated members of staff who are devoted to the cause of marine research. It is well equipped with buildings, research vessels, and scientific instruments.

There is, however, still room for improvement - how else should it be - especially with regard to positions for further staff members, as the number of tasks, the work-load, has increased.

An agreement has been negotiated between the $\mathrm{BAH}$ and the Universities of Hamburg and Kiel concerning modes of co-operation. The staff of the BAH are unanimous in their approval of closer co-operation with the universities, at the same time hoping to retain thereby their independence. 